\title{
Chlorophyll-derived fatty acids regulate expression of lipid metabolizing enzymes in liver - a nutritional opportunity
}

Oléagineux, Corps Gras, Lipides. Volume 8, Numéro 1, 39-44, Janvier - Février 2001, Dossier : Deutsche Gesellschaft für Fettwissenschaft - Association française pour l'étude des corps gras

Auteur(s) : Christian WOLFRUM, Friedrich SPENER, Department of Biochemistry, University of Münster, Wilhem-Klemm-Str. 2, 48149 Münster, Germany.

Résumé : Les valeurs nutritives des différentes classes d'acides gras sont généralement évaluées à partir de leurs structures saturées, mono-insaturées et poly-insaturées, en considérant implicitement que ce sont des chaînes linéaires. Dans cet article, nous nous intéressons aux acides phytanique et pristanique, dérivés de la chlorophylle, qui sont des constituants lipidiques isoprénoïques ramifiés, mineurs dans l'alimentation, mais dont la valeur nutritionnelle est inconnue. Après une description de la machinerie enzymatique responsable de la dégradation de ces acides gras alimentaires dans le peroxysome, nous montrons, en utilisant comme modèle la souris et une lignée cellulaire humaine, qu'ils induisent fortement l'expression des enzymes responsables de la beta-oxydation des acides gras à chaîne linéaire dans le peroxysome. Nous résumons les connaissances actuelles sur le mécanisme de la transduction du signal des acides gras dans le noyau, qui implique des contacts protéine/protéine entre un récepteur activé proliférateur du peroxysome (PPAR) et une protéine de liaison des acides gras (FABP). Dans cette étape de transduction, les acides gras ramifiés sont même les plus efficaces. Enfin, sur la base de cette interaction nutriment/gène, nous discutons les possibilités nutritives et les aspects thérapeutiques des acides gras dérivés de la chlorophylle.

Mots-clés : acide phytanique, acide pristanique, régulation des gènes, récepteur activé proliférateur du peroxysome (PPAR), protéine de liaison des acides gras (FABP), beta-oxydation.

Summary : Nutritional values of fatty acid classes are normally discussed on the basis of their saturated, monounsaturated and polyunsaturated structures with implicit understanding that they are straight-chain. Here we focus on chlorophyll-derived phytanic and pristanic acids that are minor isoprenoid branched-chain lipid constituents in food, but of unknown nutritional value. After describing the enzyme machinery that degrades these nutrient fatty acids in the peroxisome, we show by the criteria of a mouse model and of a human cell culture model that they induce with high potency expression of enzymes responsible for beta-oxidation of straight-chain fatty acids in the peroxisome. We summarize present mechanistic knowledge on fatty acid signaling to the nucleus, which involves protein/protein contacts between peroxisome proliferator activated receptor (PPAR) and fatty acid binding protein (FABP). 
In this signaling event the branched-chain fatty acids are the most effective ones. Finally, on the basis of this nutrient-gene interaction we discuss nutritional opportunities and therapeutic aspects of the chlorophyll-derived fatty acids.

Keywords : phytanic acid, pristanic acid, gene regulation, peroxisome proliferator activated receptor (PPAR), fatty acid binding protein (FABP), beta-oxidation.

\section{ARTICLE}

As the technical research centre for the French fats and oils industries, the first role of ITERG is to be a partner of the producers, processors and packers of oils and fats. We have been asked three year ago to focus our attention on electronic nose application. Our main question during this two year work has been "is it possible to use an electronic nose (EN) for the detection of sensory defects in virgin olive oil?"

The aim of this study was to determine if EN could be used as a first screening of virgin olive oils in order to detect samples with sensory defects. We have never thought that EN could replace sensory assessment, but it could be considered as a complementary tool to sensory panel.

\section{Techniques used}

* ITERG's panel is composed of 10 trained panelists and has an agreement from the International Olive Oil Council (IOOC).

* Electronic nose used is a FOX 3000 from Alpha MOS company. It is equipped with a static headspace autosampler HS 500. Sensors are formed of a ceramic layer covered with metal oxide such as tin or tungsten, which may also contain traces of palladium or germanium. They are heated around $400^{\circ} \mathrm{C}$. Oxygen adsorbed on the surface of the sensor oxidizes the volatile compounds present in the sample headspace. This oxidation generates a resistance falling which is recorded. Because sensors are not specific, it is necessary to use several of them in order to get a composite signal. In the FOX 3000, there are two cells containing each six metal oxide sensors, which are always flushed by pure synthetic air. Static headspace is generated in a $10 \mathrm{ml}$ vial using 2 grams of oil, during 15 minutes at $50^{\circ} \mathrm{C} .2 .5 \mathrm{ml}$ of the gaseous phase are injected in the EN. Synthetic air $(250 \mathrm{ml} / \mathrm{min})$ and conditioning unit (ACU500) are used in order to have a constant composition of air and humidity. Sensor resistance is measured during 2 minutes at the rate of one acquisition every second. Data provided by the 12 sensors are expressed as the maximum percentage change in resistance (deltaR/ $R_{0}$ ).

* Static headspace coupled with gas chromatography (GC), using the autosampler HS 500, has provided some information about partition coefficients between olive oil and air. 


\section{Reference method: sensory analysis}

European Community introduced in 1992 sensory assessment based on the IOOC method for the quality control of olive oils. The profile sheet used is divided in two parts: attributes of quality (such as olive fruity, bitter, pungent) and attributes of defects (such as musty, fusty, rancid, winey). The intensity of each attributes is quantified on an unipolar scale ranging from 0 to 10 . An overall mark is given to the sample (from 9 to 1 ) according to the intensities of fruitiness and the maximum defect. For example, when the intensity of the major defect is slight, the overall mark is 6 . When it's medium, the overall mark is 5 . In the international trade standard applying for olive oils, products are classified in four grades depending on their sensory characteristics and free acidity: "extra virgin", "virgin", "ordinary virgin" and "lampante virgin".

Figure 1 presents results for sample 1 (bars in yellow) which has no defect. It's overall mark then has to be higher than 6.5 so this oil has the grade "extra virgin". The grey sample presents a fusty defect with an intensity of 8 . The overall mark is then 3 and the oil has the grade "lampante virgin".

In order to test EN, more than 80 samples have been collected and then evaluated by ITERG's panel according to CEE 2568/91 method, and by EN. Defects that are found most often are fusty, musty and rancid. Most of the "lampante virgin" oils are samples provided by $\mathrm{IOOC}$ for sensory panel training.

Results of sensory assessment have been analyzed by principal component analysis (PCA) which allows a precise mapping of the products (Figure 2). Axis 1 is related to quality attributes (fruity, bitter, pungent), while axis 2 is related to musty and rancid and axis 3 to fusty. A discrimination of samples according their "grade" is observed. The more intense the defect is, the farther the sample is from the quality attributes area.

\section{Electronic nose results}

When looking the signal measured during nearly 3 days without doing any sample analysis (Figure 3 ), it is obvious that sensors do react during the day and are stable during the night. Because sensor baseline is linked to the activity of the lab, we are convinced that sensors are sensitive towards solvents present in laboratory atmosphere.

Seventy-eight samples of VOO collected were evaluated by EN. Results have been analyzed by principal component analysis (PCA). Because axis 1 explains almost $89 \%$ of the total variance, it is obvious that sensors are redundant (Figure 4). It was impossible to get a good discrimination between samples of the different grades of quality: "extra", "virgin", "ordinary" and "lampante". Even working with the two extreme classes ("extra " and "lampante"), no territory of the grade "lampante" could be defined.

Trying to discriminate grades which contain samples presenting different sensory defects was, may be, a too complex goal. We decided then to focus our work on the discrimination of defect in order to evaluate the specificity and sensitivity of the apparatus. Using an IOOC training sample with a welldefined defect, musty, we prepared several dilutions of this "lampante" VOO from $1 \%$ to $60 \%$ in an "extra" VOO as diluting agent. For the "musty" defect, when the percentage of the "lampante" VOO increases, half of the sensors presents a decreasing response while the other half is increasing. 
Using the same diluting "extra" VOO, dilutions of a rancid "lampante" oil up to $20 \%$ and of a fusty "lampante" oil up to $40 \%$ were prepared and evaluated by EN. Result analysis by PCA shows clearly the existence of territories for the musty, fusty and rancid defects (Figure 5). Using discriminant factorial analysis (DFA), samples were classed in 3 groups depending of their sensory defect. By cross validation, the percentage of recognition of each sample was evaluated. The only sample not well recognized is the $1 \%$ rancid diluted oil.

In order to have a more complex model, we decided to dilute "lampante" samples in two different "extra" virgin olive oils, A and B. Result analysis by PCA proves that sensors are more sensitive to the differences between the two "extra" oils than those between sensorial defects (Figure 6).

To understand these surprising results, static headspace coupled with gas chromatography was used and major components were identified by mass spectrometry.

\section{GC results}

Chromatogram of Figure 7 corresponds to an "extra" VOO and the major components of headspace are methanol and ethanol, with traces of octane and trans-2-hexenal which is claimed to be a tracer of quality. Chromatogram of Figure 8 corresponds to a "lampante" VOO with a fusty defect. Major components of headspace are methanol, ethanol, pentane with traces of octane and hexanal.

Partition coefficients in the system olive oil/air were evaluated at $50^{\circ} \mathrm{C}$. At equilibrium, volatiles such as t-2-hexenal, hexanal, 3-methyl-butanol or 1-octen-3-ol are mainly found in the liquid phase, while alcohols, pentane and ethyl acetate can be found in the gas phase (Table 1). As an example, at the same concentration in the liquid phase, headspace is 25 times richer in ethanol than in hexanal or 200 times richer in ethanol than in 1-octen-3-ol. These results explain why chromatograms of "extra" and "lampante" VOO are scarcely different.

"Extra" VOO headspace is mainly characterized by very high concentrations in the gaseous phase of methanol and ethanol (Table 2), between 10 and 50ppm (or mul per liters). It is also the case for "lampante" VOO. Concentrations of most of volatiles of interest (t-2-hexenal, hexanal, 3-methylbutanol or 1-octen-3-ol) are very small in static headspace and they are sometimes hard to detect. Comparing concentrations in both phases, liquid and gaseous, make it obvious that static headspace is not the best way to discriminate samples.

Nevertheless, taking into account the surface of 10 components of the headspace, PCA product mapping indicates that a discrimination between "extra" and "lampante" VOO is possible. But it isn't the case for the intermediate grades: "virgin" and "ordinary".

Sensitivity of sensors towards volatiles of olive oil aroma was evaluated by contaminating a sunflower oil with different chemicals (Figure 9). After subtracting the signal given by the uncontaminated oil, concentration of volatile compound necessary to get $10 \%$ variation of the signal was calculated. For hexanal, this gaseous concentration is around $6 \mathrm{mul} / \mathrm{l}$. None of the oils collected had such a high concentration of hexanal! 


\section{CONCLUSION}

Metal oxide sensors are sensitive to laboratory atmosphere; no discrimination is obtained with EN between the 4 sensory grades of virgin olive oil. Moreover, sensors are more sensitive to differences between 2 "extra virgin" oils than those between sensory defects. Static headspace is rich in alcohols (methanol, ethanol), poor in aroma components so it isn't the best tool to discriminate VOO.

In conclusion, EN coupled with static headspace is not able to detect sensory defects of virgin olive oil at the moment.

\section{Aknowledgement}

Thanks to ACTIA (Association de coordination technique pour l'industrie agro-alimentaire, France), Lesieur and Astra companies, Patrick Mielle from Inra Dijon.

Illustrations

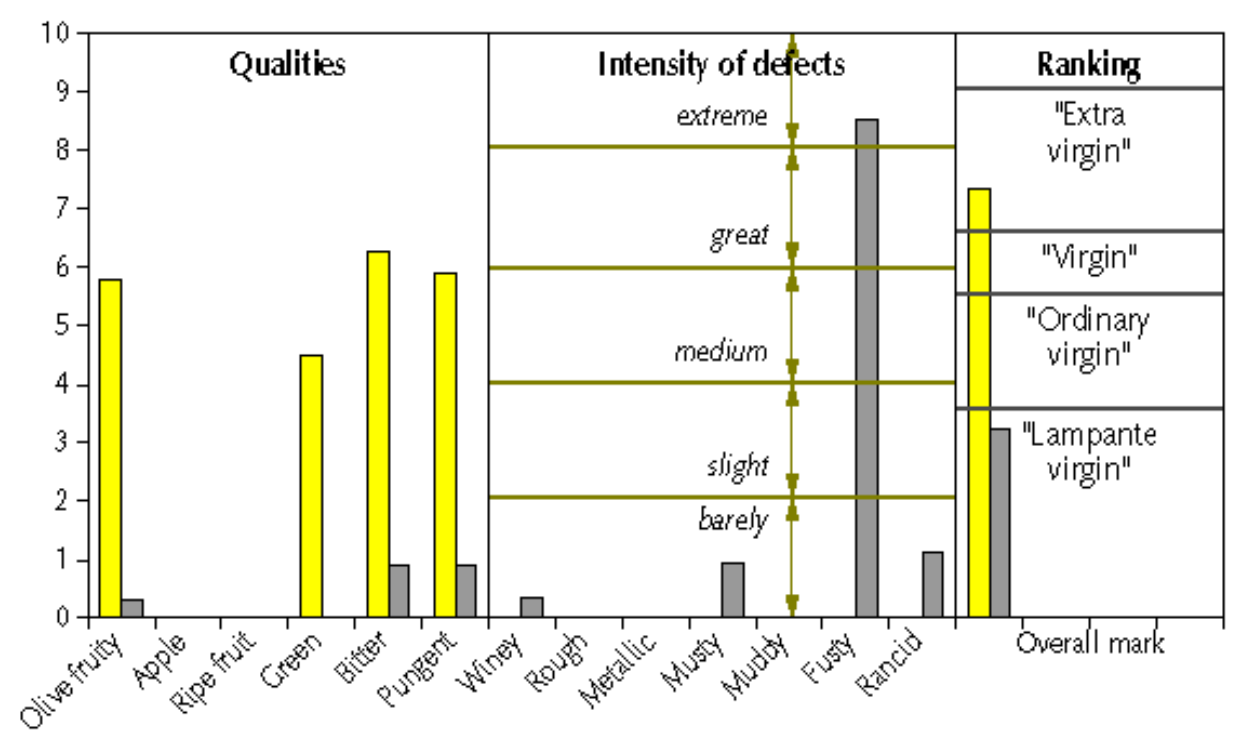

Figure 1. Sensory analysis - International trade standard (JOCE 656/95). 


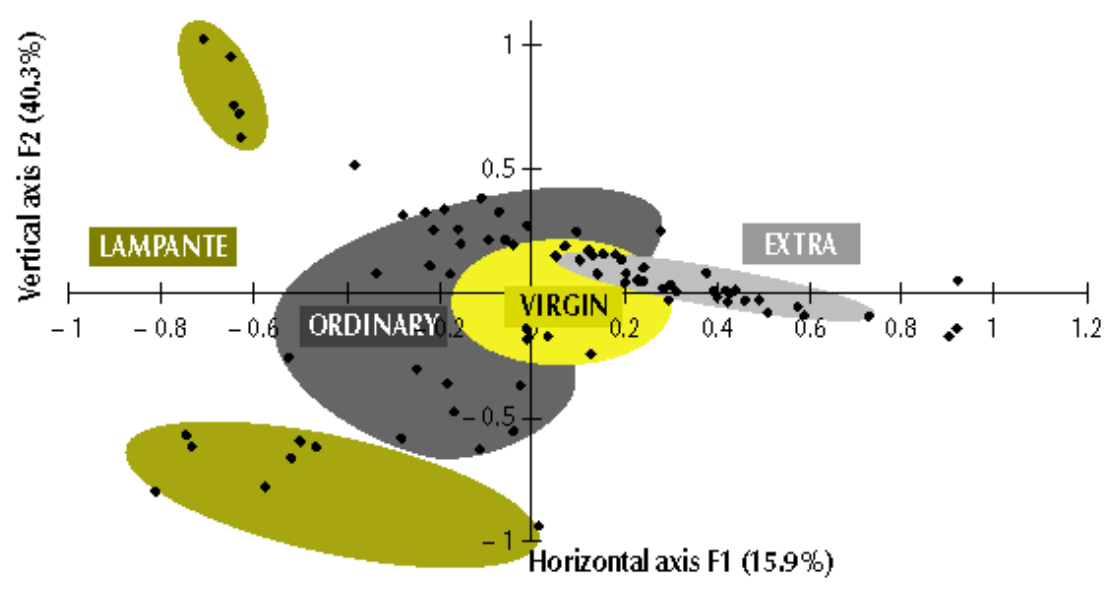

Figure 2. Quality control of VOO - Sensory analysis results (PCA). Product mapping, 78 oils, 8 descriptors.

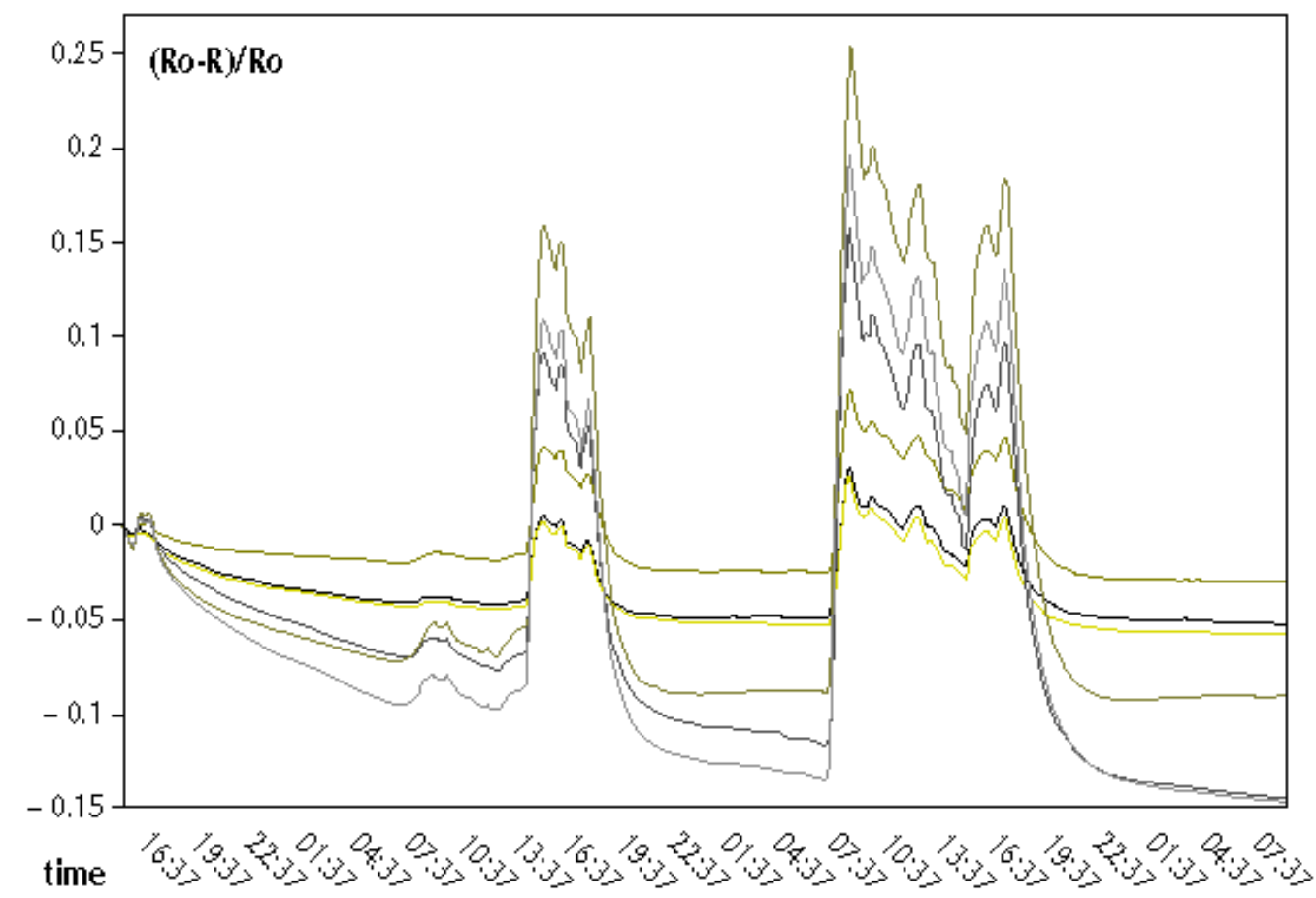

Figure 3. EN - Stability of MOS on 65 hours. 


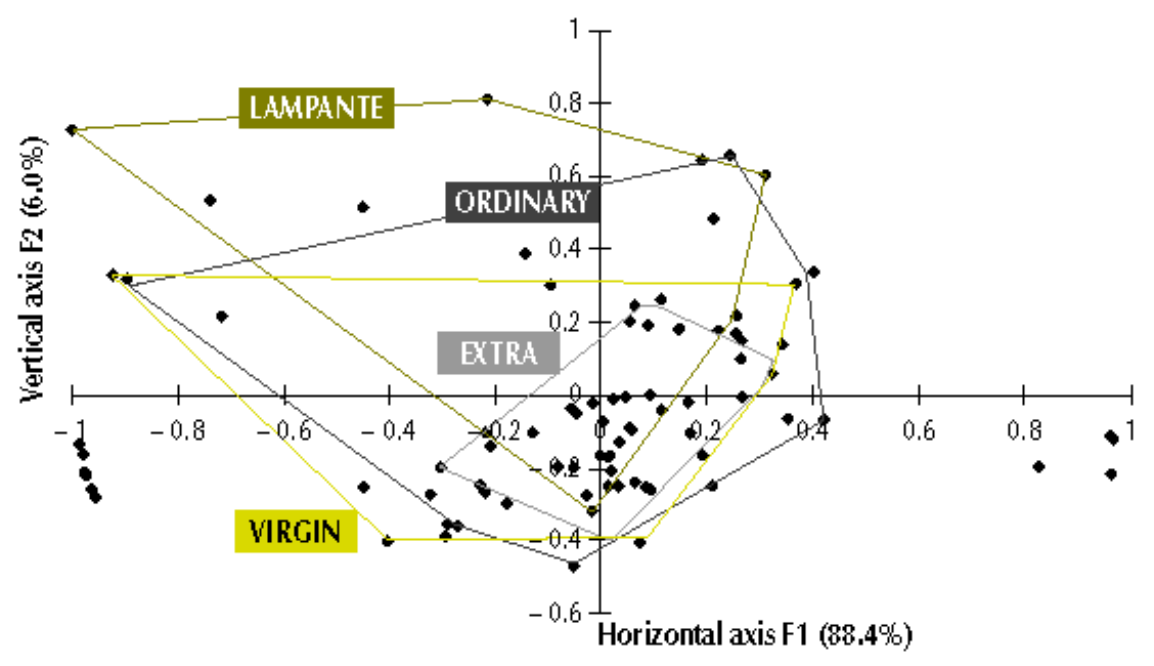

Figure 4. Quality control of VOO - Electronic nose results (PCA). Product mapping, 78 oils, 12 MOS.

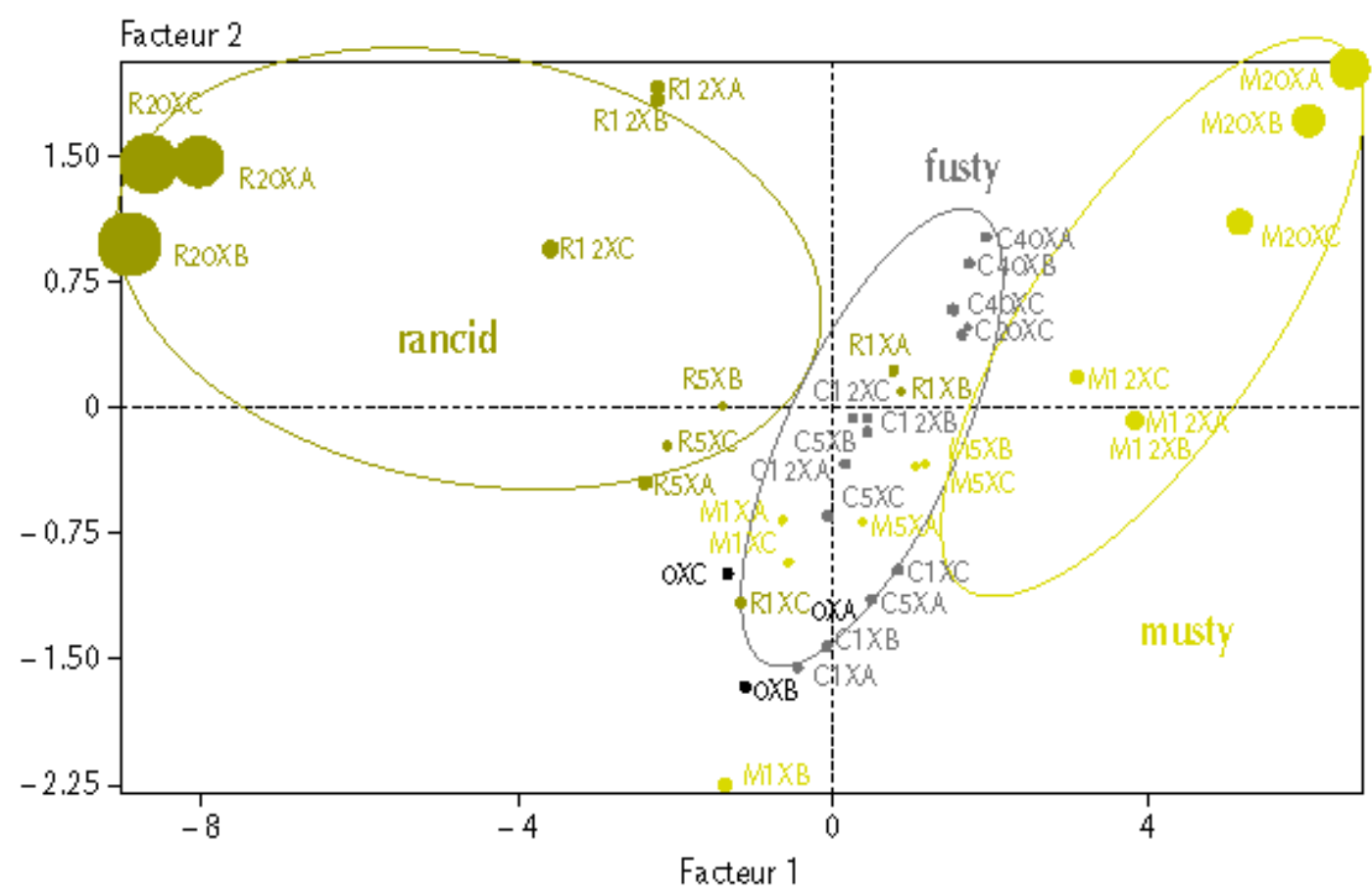

Figure 5. EN - Dilution of 3 lampante oils in 1 extra virgin olive oil (PCA). Product mapping, 14 samples, 3 repeats, 12 MOS. 


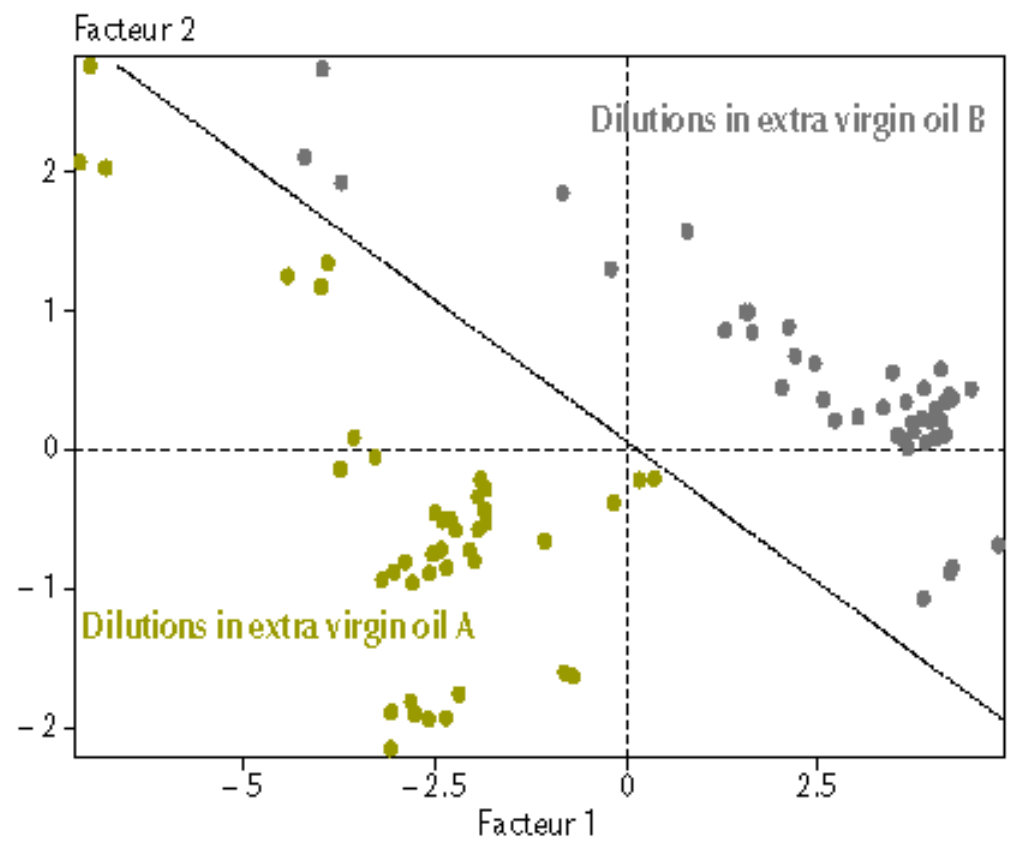

Figure 6. EN - Dilution of 3 lampante oils in 2 extra virgin olive oils (PCA). Product mapping, 24 samples, 3 repeats, 12 MOS. 


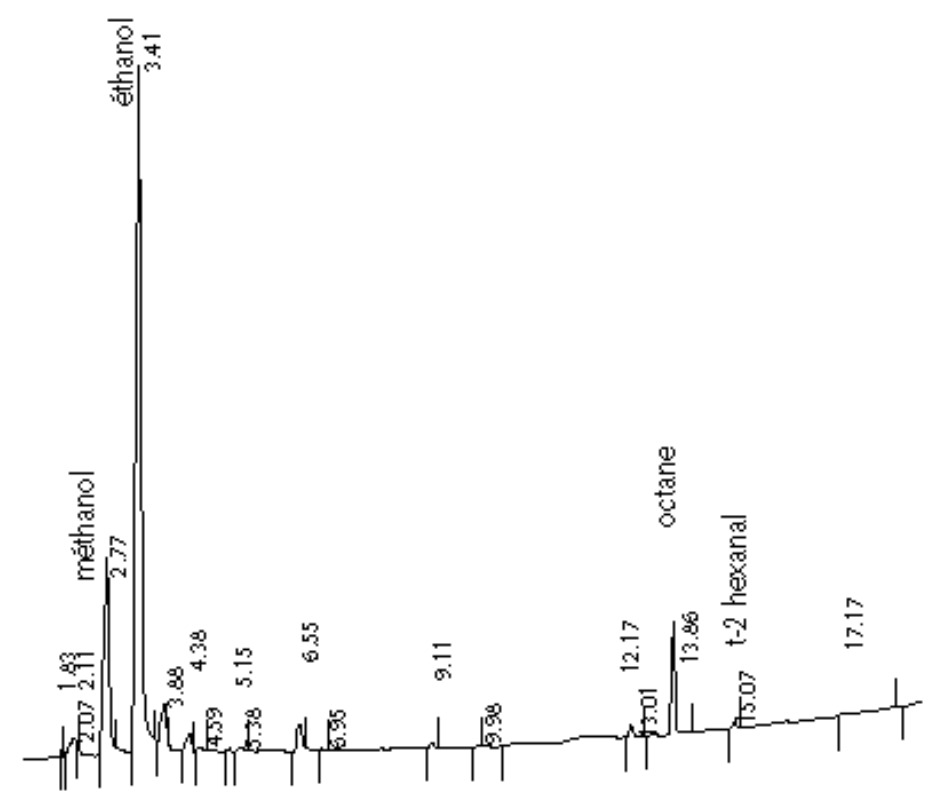

Figure 7. HS/GC - Chromatogram of an extra virgin olive oil.

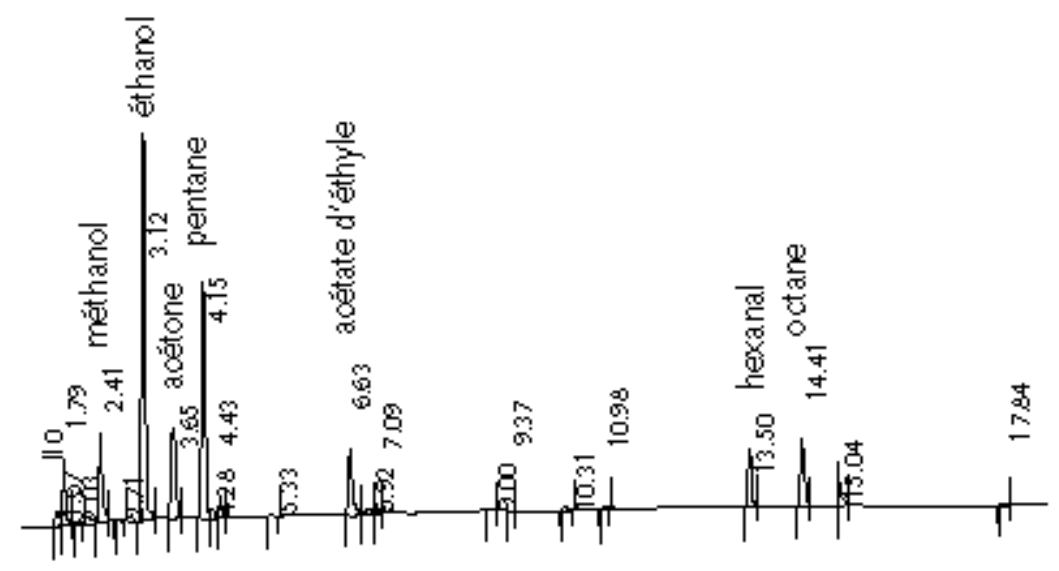

Figure 8. HS/GC - Chromatogram of an lampante virgin olive oil. 


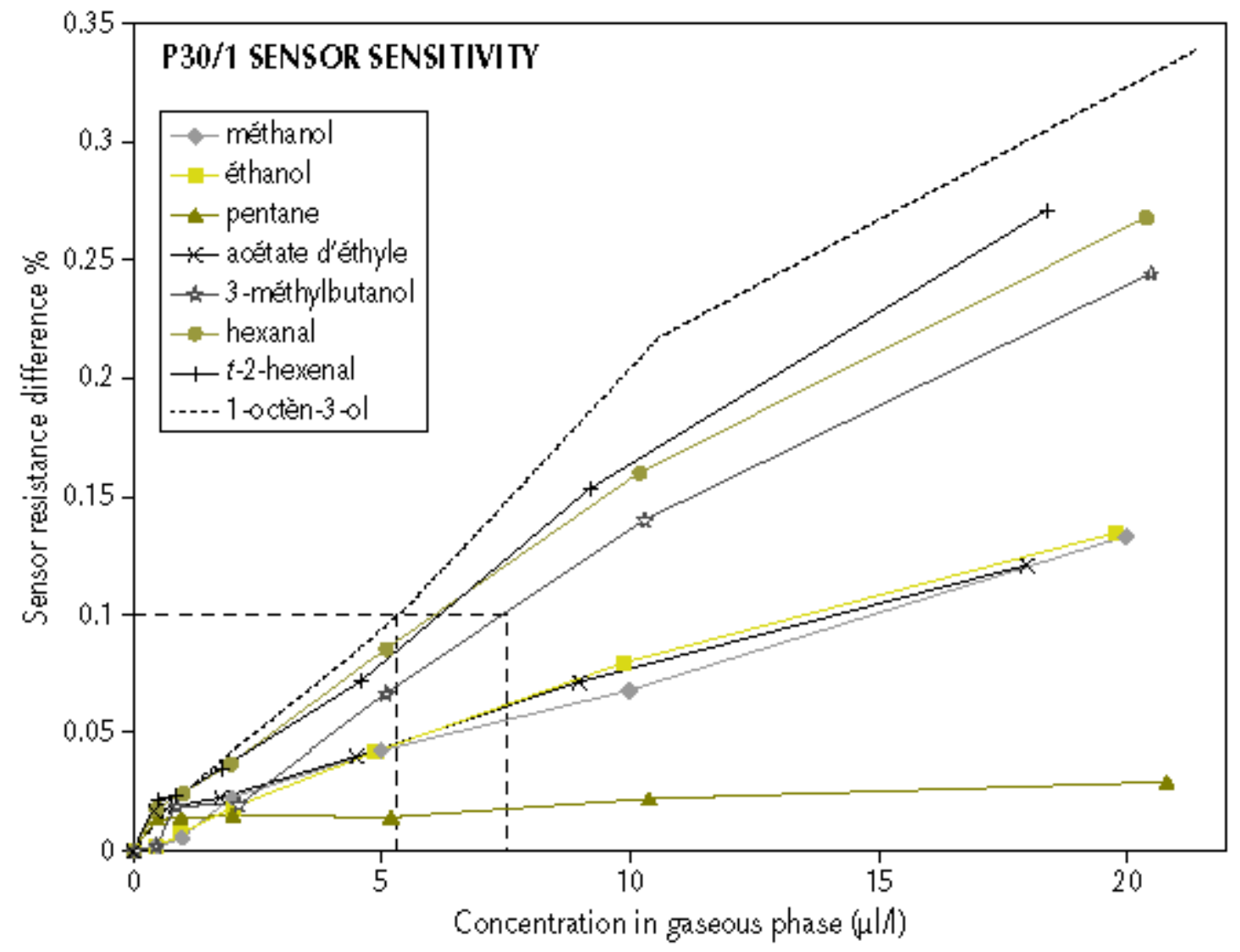

Figure 9. EN - Sensitivity to some volatiles in VOO. 
Table 1. HS/GC - Distribution coefficients in VOO at

$50^{\circ} \mathrm{C}$.

\begin{tabular}{|c|c|c|}
\hline Compounds & Q gas (mug) & Q lii \\
\hline Methanol & 1 & 13 \\
\hline Ethanol & 1 & 22 \\
\hline Pentane & 1 & 21 \\
\hline Ethyl acetate & 1 & 62 \\
\hline 3-methyl-butanol & 1 & 470 \\
\hline Hexanal & 1 & 550 \\
\hline $\mathrm{t}-2$-hexenal & 1 & 980 \\
\hline
\end{tabular}

Table 2. HS/GC - Concentrations of some volatiles in VOO.

\begin{tabular}{l|c|l|c|c} 
Quality & $\begin{array}{c}\text { Nb of } \\
\text { samples }\end{array}$ & Volatiles & $\begin{array}{c}\text { Conc. } \\
\text { in oil (ppm) }\end{array}$ & $\begin{array}{c}\text { Conc. } \\
\text { in air (ppm) }\end{array}$ \\
\hline EXTRA & 5 & Trans2-hexenal & $3-21$ & $0.2-1.2$ \\
& & Methanol & $3-4$ & $37-50$ \\
& & Ethanol & $2-10$ & $10-53$ \\
& & Pentane & $<1$ & $<4$ \\
& & Hexanal & $<3$ & $<0.3$ \\
& & Ethyl acetate & $<5$ & $<5$ \\
\hline \multirow{2}{*}{ LAMPANTE } & \multirow{2}{*}{} & Trans2-hexenal & $<4$ & $<0.2$ \\
& & Methanol & $1-8$ & $12-100$ \\
& & Ethanol & $1-45$ & $5-240$ \\
& & Pentane & $1-2(22)$ & $3.6-7.1$ \\
& & Hexanal & $2-20(400)$ & $0.2-2$ \\
& & Ethyl acetate & $5-11(100)$ & $5-11$
\end{tabular}

